\title{
Correction to: Role of Texture and Microstructural Developments in the Forming Limit Diagrams of Family of Interstitial Free Steels
}

Basavaraj H. Vadavadagi, H.V. Bhujle, and Rajesh Kisni Khatirkar

Published online: 2 August 2021

\section{Correction to: JMEPEG}

\section{https://doi.org/10.1007/s11665-021-05992-x}

Notation for the plastic anisotropy ratio $(\overline{\mathrm{r}})$ and strain $(\bar{\varepsilon})$ was rendered incorrectly in the PDF version of this article as originally published. The notation has been corrected throughout that version of the article.
Publisher's Note Springer Nature remains neutral with regard to jurisdictional claims in published maps and institutional affiliations.

The original article can be found online at https://oi.org/10.1007/ s11665-021-05992-x.

Basavaraj H. Vadavadagi and H.V. Bhujle, S.D.M. College of Engineering \& Technology, Dhavalagiri, Dharwad, Karanataka 580002, India; and Rajesh Kisni Khatirkar, Visvesvaraya National Institute of Technology (VNIT), South Ambazari Road, Nagpur, Maharashtra 440010, India. Contact e-mail: vbasavaraj99@gmail.com. 